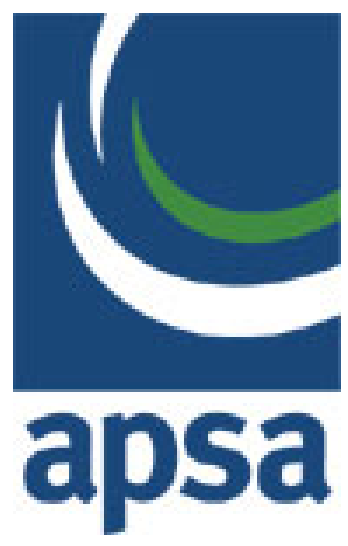

Power Politics and International Trade Author(s): Joanne Gowa and Edward D. Mansfield

Source: The American Political Science Review, Vol. 87, No. 2 (Jun., 1993), pp. 408-420

Published by: American Political Science Association

Stable URL: http://www.jstor.org/stable/2939050

Accessed: 29/01/2009 14:24

Your use of the JSTOR archive indicates your acceptance of JSTOR's Terms and Conditions of Use, available at http://www.jstor.org/page/info/about/policies/terms.jsp. JSTOR's Terms and Conditions of Use provides, in part, that unless you have obtained prior permission, you may not download an entire issue of a journal or multiple copies of articles, and you may use content in the JSTOR archive only for your personal, non-commercial use.

Please contact the publisher regarding any further use of this work. Publisher contact information may be obtained at http://www.jstor.org/action/showPublisher?publisherCode=apsa.

Each copy of any part of a JSTOR transmission must contain the same copyright notice that appears on the screen or printed page of such transmission.

JSTOR is a not-for-profit organization founded in 1995 to build trusted digital archives for scholarship. We work with the scholarly community to preserve their work and the materials they rely upon, and to build a common research platform that promotes the discovery and use of these resources. For more information about JSTOR, please contact support@jstor.org. 


\title{
POWER POLITICS AND INTERNATIONAL TRADE
}

\author{
JOANNE GOWA Princeton University \\ EDWARD D. MANSFIELD Columbia University
}

\begin{abstract}
$R$ ecent literature attributes the relative scarcity of open international markets to the prisoner's dilemma structure of state preferences with respect to trade. We argue that the prisoner's dilemma representation does not reflect the most critical aspect of free trade agreements in an anarchic international system, namely, their security externalities. We consider these external effects explicitly. Doing so leads us to two conclusions: (1) free trade is more likely within, rather than across, political-military alliances; and (2) alliances are more likely to evolve into free-trade coalitions if they are embedded in bipolar systems than in multipolar systems. Using data drawn from an 80-year period beginning in 1905, we test these hypotheses. The results of the analysis make it clear that alliances do have a direct, statistically significant, and large impact on bilateral trade flows and that this relationship is stronger in bipolar, rather than in multipolar, systems.
\end{abstract}

I n the early 1970 s, students of international relations began what would become a long and heated debate about the political correlates of open international markets. Recently, however, an important element of consensus has begun to emerge: most contributors to this debate now seem to agree that the prisoner's dilemma structure of state preferences with respect to trade explains the relative dearth of open international markets. ${ }^{1}$

Here, we argue that what has become the standard prisoner's dilemma representation neglects the most critical aspect of free-trade agreements in the anarchic international system, namely, their security externalities. We consider these external effects explicitly. In order to do so, we construct and analyze a simple game-theoretic model. The results of this analysis demonstrate that tariff games between allies differ systematically from those played between actual or potential adversaries.

These differences imply that free trade is more likely within, rather than across, political-military alliances. However, our analysis also suggests that the evolutionary prospects of alliances vary: those that are the products of bipolar systems are more likely to evolve into free-trade coalitions than are their multipolar counterparts. Less credible exit threats and clearer responsibilities for alliance stability explain the advantage of a bipolar system.

We test this argument using data drawn from an 80 -year period beginning in 1905 . The empirical analysis supports our argument. It demonstrates that alliances have a direct, statistically significant, and large effect upon bilateral trade. Moreover, it shows that on average, alliances have a much stronger effect on trade in a bipolar than in a multipolar world. ${ }^{2}$

\section{POWER, TRADE, AND TARIFFS}

Unlike many arguments about the use of economic statecraft, ours is cast at the macroeconomic rather than at the microeconomic level. In other words, the argument we advance here is not about, for example, attempts to use economic statecraft to embargo exports of particular products or to inhibit the development of technologically advanced industries in other countries. ${ }^{3}$ Instead, it is an argument that is based upon the effect of free trade on the real income and power potential of states.

We argue that the play of power politics is an inexorable element of any agreement to open international markets because trade produces security externalities. ${ }^{4}$ These externalities arise because the source of gains from trade is the increased efficiency with which domestic resources can be employed. This increased efficiency itself frees economic resources for military uses (Baldwin 1985, 216; Hirschman 1980, 14; McKeown 1982, 225; idem 1984, 232; Root 1984, 75; Srinivasan 1987, 352). As a consequence, trade enhances the potential military power of any country that engages in it.

The anarchic structure of the international system, in turn, compels its constituent states to attend closely to the potential military power of both allies and potential or actual adversaries. It does so because the absence of any supranational authority in the international system enables a state to resort to force at any time to achieve its goals. The probability that a state will do so depends in part upon its power, which, in turn, depends partly upon its real income.

As a consequence, the real income gains that motivate free trade are also the source of the security externalities that can either impede or facilitate it: trade with an adversary produces a security diseconomy; trade with an ally produces a positive externality. In either case, agreements to open international markets create a divergence between the private and social costs of trade. ${ }^{5}$ A socially suboptimal level of trade results, suggesting that government intervention in trade can be welfare-enhancing for the nation as a whole.

Figure 1 illustrates this situation. It shows the domestic market for a good that can also be imported at its world price, $\mathrm{P}_{\mathrm{w}}$, which is the private marginal 


\section{FIGURE 1}

Trade with an Adversary

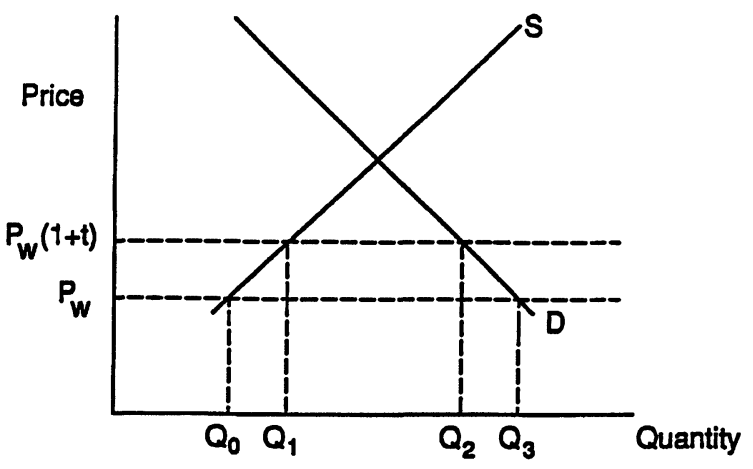

cost of imports. In the absence of government intervention, domestic output is $Q_{0}$; domestic demand is $\mathrm{Q}_{3}$; and the amount imported is the difference between them $\left(Q_{3}-Q_{0}\right)$. Because of the external diseconomy that trade with actual or potential adversaries generates, however, the marginal social cost of imports is higher, $P_{w}(1+t)$. This market failure can be eliminated by a tariff, $t$, which raises domestic output to $Q_{1}$, lowers domestic demand to $Q_{2}$, and reduces imports to $Q_{2}-Q_{1} \cdot{ }^{6}$ Government intervention in trade to correct this distortion is, in addition, a first-best policy: the market failure in this instance does not originate in a domestic distortion but arises, instead, in trade itself. ${ }^{7}$

\section{OPTIMAL TARIFF GAMES}

Successful intervention in trade to correct the security externalities associated with it depends upon the ability of a country to affect the real income of the state which is its target. Although any tariff will distort resource allocation in the target country and therefore decrease its real income, it will do so without imposing net costs on the home country only if the latter can affect its terms of trade.

Thus, in the absence of the requisite market power, a tariff will impose costs primarily upon the state that levies it. In its presence, a tariff will allow a state to increase its own real income at its adversary's expense. If a state can affect world prices, then, it can use a tariff to narrow the gap between the private and social costs of trade. Thus, a tariff can be welfaresuperior to a policy of free trade for a state in an anarchic international political system.

This argument is, of course, a variant of the traditional optimal tariff argument. Its novelty inheres in the two conclusions that emerge from our discussion below: (1) tariff games between allies differ systematically from those played between adversaries; and (2) intraalliance free trade is more likely in a bipolar than in a multipolar system.

\section{The Standard Optimal Tariff Game}

The payoff matrix of the standard optimal tariff game is shown in Figure 2. This game is a prisoner's dilemma in which $\mathrm{T}$ is the payoff that accrues to a state that unilaterally deploys an optimal tariff, $R$ is the payoff that results if both states trade freely with each other, $\mathrm{P}$ is the return that accrues if both use optimal tariffs, and $S$ is the payoff to unilateral free trade. As the matrix makes apparent, in a one-shot game, defection is a dominant strategy. ${ }^{8}$ As a result, the inevitable outcome of this (or of a finite) game is bilateral tariffs. ${ }^{9}$

In contrast, in an infinite game or in a game in which states assume at every period that there is some positive probability that the game will continue, a variety of Pareto-improving outcomes, including that of free trade, can be realized. ${ }^{10}$ This can occur if, for example, both states adhere to a "grim" strategy, that is, begin with free trade (i.e., cooperate); trade freely in every succeeding period if the outcome of the previous period was bilateral free trade; otherwise, deploy an optimal tariff (i.e., defect). ${ }^{11}$

This strategy will sustain cooperation in a prisoner's dilemma game if the discounted sum of cooperative payoffs, $R /(1-\delta)$, is greater than the sum of the one-shot gain from defection, $\mathrm{T}$, and the discounted sum of punishment payoffs, $\delta \mathrm{P} /(1-\delta){ }^{12}$ Thus, cooperation can be sustained by a grim strategy if

\section{FIGURE 2}

The Prisoner's Dilemma

\section{Column}

\begin{tabular}{ccc|c|}
\multirow{2}{*}{ Row } & \multicolumn{1}{c}{ Cooperate } & \multicolumn{1}{c}{ Defect } \\
\cline { 3 - 4 } & Defect & $R, R$ & $S, T$ \\
\cline { 2 - 3 } & & $T, S$ & $P, P$ \\
\cline { 3 - 4 } & & &
\end{tabular}

Note: $\mathrm{T}>\mathrm{R}>\mathrm{P}>\mathrm{S}$; Row's payoffs are listed first; $(\mathrm{T}+\mathrm{S}) / 2 \leq \mathrm{R}$. 
FIGURE 3

The Prisoner's Dilemma: Adversaries

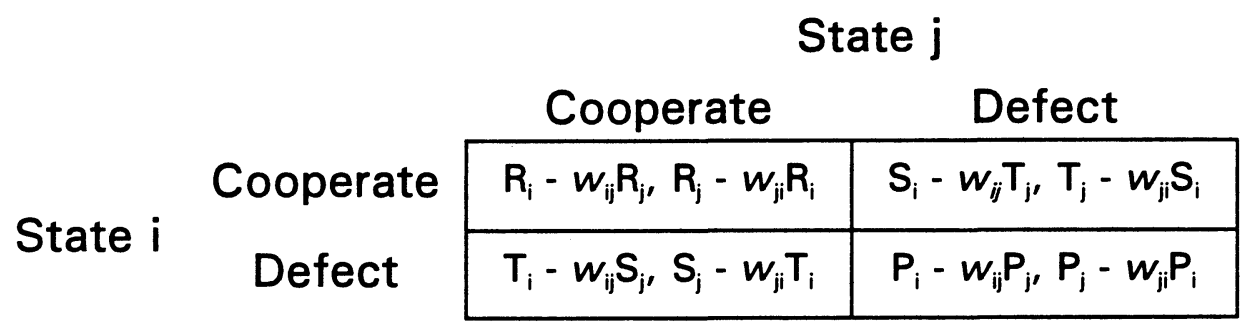

Note: This payoff matrix omits second-order effects.

$$
\mathrm{R} /(1-\delta) \geq \mathrm{T}+\delta \mathrm{P} /(1-\delta)
$$

or

$$
\delta \geq(\mathrm{T}-\mathrm{R}) /(\mathrm{T}-\mathrm{P}) .
$$

If this incentive compatibility constraint is satisfied, a grim strategy will enable free trade to emerge as the outcome of an infinite-horizon optimal tariff game. That this is possible not only in the abstract but also in the real world is suggested by the success of the General Agreement on Tariffs and Trade (GATT). Established in 1947, the GATT was created to, and did, enable states to avoid a replay of the tariff game that stymied trade among them in the interwar period. ${ }^{13}$

\section{Tariff Games Between Adversaries}

The payoff matrix of the standard optimal tariff game assumes that there is no difference between private and social returns to interstate trade. Life in an anarchic international system, however, effectively alters the matrix of the standard game. Because interstate trade in such a system produces security externalities, it creates a divergence between private and social returns that any utility-maximizing state will take into account when it calculates its payoffs from trade.

Thus, the payoffs a state assigns to the outcomes of any given trade game differ from those of the standard optimal tariff game. In the case of trade with an adversary, a state incurs a marginal social cost that the standard matrix does not reflect. This transforms the standard matrix as shown in Figure 3. In each cell, the social cost that a state, $i$, incurs is represented as a fraction, $w_{\mathrm{ij}}$, of the payoff that accrues to its adversary, $\mathrm{j}$. Thus, $w_{\mathrm{ij}} \mathrm{R}_{\mathrm{j}}$, for example, is the social cost or security diseconomy that accrues to state $i$ when it trades freely with state $j$.

This cost is represented as an increasing function of the adversary's gains from trade. This representation is based in part on what Robert Powell has described as a "very simple, highly stylized assumption about the nature of warfare": that is, the "stronger a state is economically, the more likely it is to prevail in war" $(1991,1312)$. The functional dependence of social on private returns from trade also has a sector-specific component. The increase in domestic resource efficiency that results from trade frees economic resources for military uses and, therefore, increases an adversary's actual or potential military power.

The marginal social cost of trade is represented as a fraction, $w_{\mathrm{ij}}$, of the adversary's gains from trade, partly because military power obviously does not depend only upon gross national product. It also depends, for example, on technology, skill, and the extractive potential of the state. In addition, military portfolios reflect the diversified interests of great powers. Because military resources are not completely fungible, not all additions to the military power of an adversary will weaken its trading partner. Thus, even if an adversary did divert all of its gains from trade to its military sector, its action would not necessarily inflict a social cost on its trading partner equal to the incremental addition to its military power.

When the returns from trade are adjusted to reflect its marginal social cost, the net effect is to make tariff games between adversaries more difficult to solve than is the standard optimal tariff game. Assuming that the game is iterated, free trade can be sustained in an optimal tariff game between adversaries if

$$
\left(\mathrm{R}_{\mathrm{i}}-w_{\mathrm{ij}} \mathrm{R}_{\mathrm{j}}\right) /\left(1-\delta_{\mathrm{i}}\right) \geq \mathrm{T}_{\mathrm{i}}-w_{\mathrm{ij}} \mathrm{S}_{\mathrm{j}}+\delta_{\mathrm{i}}\left(\mathrm{P}_{\mathrm{i}}-w_{\mathrm{ij}} \mathrm{P}_{\mathrm{j}}\right) /\left(1-\delta_{\mathrm{i}}\right)
$$

or

$$
\delta_{\mathrm{i}}^{*} \geq \frac{\mathrm{T}_{\mathrm{i}}-w_{\mathrm{ij}} \mathrm{S}_{\mathrm{j}}-\left(\mathrm{R}_{\mathrm{i}}-w_{\mathrm{ij}} \mathrm{R}_{\mathrm{j}}\right)}{\mathrm{T}_{\mathrm{i}}-w_{\mathrm{ij}} \mathrm{S}_{\mathrm{j}}-\left(\mathrm{P}_{\mathrm{i}}-w_{\mathrm{ij}} \mathrm{P}_{\mathrm{j}}\right)} .
$$

This condition is more difficult to satisfy than the condition that emerges from an optimal tariff game among states with independent utility functions. In a prisoner's dilemma game with payoffs of $(3,2,1,0)$, for example, the minimum discount factor that would support free trade in the standard game is .50 . In the modified game (with $w=.40$ ), the analogous figure rises to $.75 .^{14}$ Thus, the introduction of interdependent utility functions characteristic of adversarial states makes any given prisoner's dilemma more "severe" or difficult to solve. In addition, as $w$ increases, the severity of the game also increases. ${ }^{15}$ 
FIGURE 4

The Prisoner's Dilemma: Allies

\section{State j}

\begin{tabular}{|c|c|c|c|}
\hline \multirow{3}{*}{ State $\mathrm{i}$} & & Cooperate & Defect \\
\hline & \multirow{2}{*}{$\begin{array}{c}\text { Cooperate } \\
\text { Defect }\end{array}$} & $\mathbf{R}_{\mathrm{i}}+w_{\mathrm{ij}} \mathbf{R}_{\mathrm{j}}, \mathbf{R}_{\mathrm{j}}+w_{\mathrm{ji}} \mathbf{R}_{\mathrm{i}}$ & $\mathrm{S}_{i}+w_{i j} \mathrm{~T}_{\mathrm{j}}, \mathrm{T}_{\mathrm{j}}+w_{\mathrm{j} j} \mathrm{~S}_{\mathrm{i}}$ \\
\hline & & $\mathbf{T}_{\mathrm{i}}+w_{\mathrm{ij}} \mathrm{S}_{\mathrm{j}}, \mathrm{S}_{\mathrm{j}}+w_{\mathrm{ji}} \mathbf{T}_{\mathrm{i}}$ & $P_{i}+w_{i j} P_{j}, P_{j}+w_{j i} P_{i}$ \\
\hline
\end{tabular}

Note: This payoff matrix omits second-order effects.

\section{Tariff Games Between Allies}

The gains of one state impose social costs on another only if the former is an actual or potential threat to the security of the latter. When a state trades with an ally, however, it realizes both private and social benefits. In the case of allies, the security externality that trade produces is positive. As in the case of trade between adversaries, a utility-maximizing state will take account of not only private but also social returns in calculating its payoffs from trade.

Thus, the standard matrix does not apply to this case either. The transformed prisoner's dilemma matrix is shown in Figure 4. In each cell, the social benefit that that a state, $i$, realizes as a consequence of trade with an ally is represented as some fraction, $w_{\mathrm{ij}}$, of the payoff that accrues to its ally, $\mathrm{j}$. This effectively internalizes the positive security externality associated with free trade between allies. The functional form is based on reasoning analogous to that which applies in the case of trade between adversaries. The applicable incentive compatibility constraint then becomes

$$
\left(\mathrm{R}_{\mathrm{i}}+w_{\mathrm{ij}} \mathrm{R}_{\mathrm{j}}\right) /\left(1-\delta_{\mathrm{i}}\right) \geq \mathrm{T}_{\mathrm{i}}+w_{\mathrm{ij}} \mathrm{S}_{\mathrm{j}}+\delta_{\mathrm{i}}\left(\mathrm{P}_{\mathrm{i}}+w_{\mathrm{ij}} \mathrm{P}_{\mathrm{j}}\right) /\left(1-\delta_{\mathrm{i}}\right)
$$

or

$$
\delta_{\mathbf{i}}^{* *} \geq \frac{\mathrm{T}_{\mathrm{i}}+w_{\mathrm{ij}} \mathrm{S}_{\mathrm{j}}-\left(\mathrm{R}_{\mathrm{i}}+w_{\mathrm{ij}} \mathrm{R}_{\mathrm{j}}\right)}{\mathrm{T}_{\mathbf{i}}+w_{\mathrm{ij}} \mathrm{S}_{\mathbf{j}}-\left(\mathrm{P}_{\mathrm{i}}+w_{\mathrm{ij}} \mathrm{P}_{\mathrm{j}}\right)} .
$$

This condition is more easily satisfied than is the condition that emerges from either the standard prisoner's dilemma or the transformed game among adversaries. Using the same values assigned in the example above, free trade can be sustained among allies when the discount factor is .13. In addition, if $w$ exceeds the larger of $(T-R) /(T-S)$ and $(D-S) /$ $(T-S)$, free trade becomes the dominant strategy equilibrium. In short, tariff games between allies are easier to solve than tariff games between actual or potential adversaries.

\section{The Influence of Polarity}

While this model suggests that all alliances will influence trade barriers, it seems clear that alliances have exerted a stronger effect after, than before,
World War II. Inspection of the incentive compatibility constraint that applies to the intraallied tariff game suggests one explanation of this difference. All other things being equal, the extent to which allies trade freely with each other depends upon the discount factor, $\delta$. The discount factor is a function of the risk of exit, which, in turn, is a function of systemic polarity (Gowa 1989). ${ }^{16}$

The risk of exit is the threat that an ally will abandon an existing alliance to join an alternative one. For several reasons, this risk is higher in multipolar than in bipolar systems. ${ }^{17}$ First, while bipolar coalitions are the products largely of system structure, alliances in a multipolar system are the results of choice among several possible alternatives (Snyder 1984, 415). Second, in a bipolar system, realignment is impossible for either pole. By default, alliance stability is also the exclusive responsibility of each. Neither can expect any other state to prevent the defection of an ally from within its bloc (Snyder 1984). In a multipolar system, however, the interest in preserving alliance stability can be distributed across more than one pole. As a consequence, alliance stability can become problematic, as each pole seeks to transfer the burden of maintaining the alliance to another.

The implications of different exit risks for trade are clear. Any great-power member of a coalition in a multipolar world has strong incentives to discriminate among its allies in terms of its investment in them, because its allies confront divergent opportunity costs of exit. In contrast, the incentive to discriminate in a bipolar world is much weaker, since allies are much more uniformly and securely locked into coalitions. In a bipolar world, in other words, the gains from trade can be more easily privatized. As a consequence, investments in allies in a multipolar system are likely to be expressed in the form of discriminatory trade preferences; in a bipolar system, free trade is the more likely outcome.

In short, because the risk of exit is lower in a bipolar than in a multipolar system, the security externalities of any free-trade agreement are more likely to remain internalized within the alliances of the former than in those of the latter. As a result, allies in a multipolar system will tend to discount the 
future benefits accruing from open markets among them more heavily than will their bipolar counterparts. The greater stability of bipolar coalitions allows the value of future benefits to approximate present benefits more closely.

For any given structure of payoffs, then, free trade is more likely to emerge within the alliances of a bipolar than in those of a multipolar system. It is not surprising, therefore, that the effect of alliances on trade seems to have been greater after rather than before World War II. We shall now subject this and our more general hypothesis about the impact of alliances on trade to a systematic empirical test.

\section{THE RESEARCH DESIGN}

Empirical analyses of the influence of political factors on bilateral trade are relatively rare. However, because several important studies do address closely related topics, we want to examine them briefly here. One group of studies examines the effects on bilateral trade of preferential trading arrangements (PTAs), such as customs unions and free-trade areas. Many of these analyses conclude that PTAs have done much to promote trade among member nations (Aitken 1973; Linnemann 1966; Pelzman 1977; Tinbergen 1962). Another group of studies uses events data to analyze the impact on bilateral trade of political conflict and cooperation. These analyses conclude that bilateral trade tends to be lower when the participants are engaged in conflicts than when political relations between them are relatively cooperative (Pollins 1989a, 1989b).

Our analysis differs from these studies in three ways. First, clear differences exist between alliances and economic arrangements that are explicitly designed to promote trade among their members. Moreover, since many PTAs have formed among political allies (Mansfield 1993), our model may at least partially endogenize their effects on bilateral trade. Second, it is unlikely that a very strong relationship exists between alliances and measures of conflict and cooperation based on events data: there may be a considerable degree of low-level conflict among members of an alliance and substantial cooperation among states that are not allied. Third, these studies examine the determinants of bilateral trade after 1945 . To adequately test our model, we need to consider a much longer time period. Hence, while previous analyses have yielded important insights into the effects of certain aspects of international politics on trade, they do not analyze either the same dimension of international politics or the same period of time as we do here. ${ }^{18}$

Based on our argument, we expect that (1) fewer trade barriers will exist within than across alliances; and (2) intraalliance free trade will be more likely within bipolar than within multipolar systems. While we would prefer to test these hypotheses directly, it is not possible to do so. Reliable tariff data do not exist for all countries over the entire time span that we analyze. However, to the extent that alliance patterns explain tariffs and that tariffs, in turn, explain the volume of trade, tariffs are endogenized, and we can focus on the relationship between alliances and trade. ${ }^{19}$ As a result, we examine the effects of alliances on bilateral trade flows.

Ideally, we would include in our sample all major powers and their allies. However, data limitations led us to focus on trade relations among the United States, Great Britain, France, Italy, Germany, the Soviet Union, ${ }^{20}$ and Japan during the period from 1905 to 1985 . Though this is clearly a limited sample, these states include most of the major powers in the international system during this period (Levy 1983; Small and Singer 1982). Moreover, since we expect the impact of alliances on trade to be most pronounced in cases of alliances involving major powers, this analysis will offer an important, though preliminary, test of our model. ${ }^{21}$

We also expect that bilateral alliances will affect trade flows more strongly than will multilateral alliances. While the aggregate flow of trade across a group of more than two states may be higher when these states are engaged in an alliance than when they are not, this need not imply that all bilateral trade flows among these states will be higher under these circumstances. For example, the existence of an alliance among states A, B, C, and D would be expected to produce an increase in the total trade among these states. This, however, would not necessarily lead to an increase in bilateral trade between $A$ and $B$. Indeed, A and B may engage in less commerce during the course of this alliance than in the absence of the alliance (although they would be expected to offset this by trading more with $\mathrm{C}$ and/or D). But if our argument holds, bilateral alliances should be directly related to bilateral trade. Under these circumstances, the effects of alliances on aggregate intraalliance trade can be assessed directly by examining trade flows between the two partners.

\section{THE MODEL}

In this section, we develop a simple model of the relationship between alliances and bilateral trade. It is clear that any analysis of this sort should incorporate economic, as well as political, determinants of trade. Among economists, gravity models of bilateral trade flows have been widely used (Aitken 1973; Anderson 1979; Deardorff 1984, 503-4; Frankel 1992; Leamer and Stern 1970, 145-70; Linnemann 1966; Pelzman 1977; Tinbergen 1962). In order to analyze the economic determinants of bilateral trade, we use a wellknown variant of this model, which includes the gross national product (GNP) and the population of both the importer and the exporter, as well as the geographic distance between the two states. Consistent with previous research based on this model, we expect that the nominal value of bilateral trade will be directly related to the nominal GNP of both the importer and the exporter and inversely related to the 
population of both the importer and exporter and to the geographic distance between them.

In addition to GNP, population, and distance, we include two variables related to alliances in our model: one indicating whether a bilateral alliance exists between the trading partners and one indicating whether a multilateral alliance exists between these states. Finally, because we expect interstate wars to reduce trade among the belligerents, we also include a variable that indicates whether or not the importer and exporter are at war.

Hence, our model is

$$
\begin{aligned}
& \log \mathrm{X}_{\mathrm{ij}(\mathrm{t})}=\log \mathrm{A}+\mathrm{B}_{1} \log \mathrm{Y}_{\mathrm{i}(\mathrm{t}-1)}+\mathrm{B}_{2} \log \mathrm{Y}_{\mathrm{j}(\mathrm{t}-1)} \\
& \quad+\mathrm{B}_{3} \log \mathrm{P}_{\mathrm{i}(\mathrm{t}-1)}+\mathrm{B}_{4} \log \mathrm{P}_{\mathrm{j}(\mathrm{t}-1)} \\
& \quad+\mathrm{B}_{5} \log \mathrm{D}_{\mathrm{ij}(\mathrm{t}-1)}+\mathrm{B}_{6} \log \mathrm{BA}_{\mathrm{ij}(\mathrm{t}-1)} \\
& +\mathrm{B}_{7} \log \mathrm{MA}_{\mathrm{ij}(\mathrm{t}-1)}+\mathrm{B}_{8} \log \mathrm{War}_{\mathrm{ij}(\mathrm{t}-1)}+\log \mathrm{z}_{\mathrm{ij},}
\end{aligned}
$$

where $\log X_{i j(t)}$ is the natural logarithm of the nominal value of exports (expressed in U.S. dollars) by state $i$ to state $j$ in year $t,{ }^{22} \log Y_{i(t-1)}$ is the natural logarithm of the nominal GNP (expressed in U.S. dollars) of state $i$ in year $t-1,{ }^{23} \log Y_{j(t-1)}$ is the natural logarithm of the nominal GNP (expressed in U.S. dollars) of state $\mathrm{j}$ in year $\mathrm{t}-1, \log \mathrm{P}_{\mathrm{i}(\mathrm{t}-1)}$ is the natural logarithm of the population of state $i$ in year $t-1,{ }^{24}$ $\log P_{j(t-1)}$ is the natural $\log$ arithm of the population of state $j$ in year $t-1, \log D_{i j(t-1)}$ is the natural logarithm of the geographic distance between states $i$ and $j$ in year $t,{ }^{25} \log \mathrm{BA}_{\mathrm{ij}(\mathrm{t}-1)}$ is a dummy variable that equals 1 if an alliance exists between states $i$ and $j$ in year $t-$ 1 that is comprised of no members except $i$ and $j$ (and 0 otherwise), ${ }^{26} \log \mathrm{MA}_{\mathrm{ij}(\mathrm{t}-1)}$ is a dummy variable that equals 1 if an alliance exists between states $i$ and $j$ in year $t-1$ that includes at least one additional member (and 0 otherwise), log $\operatorname{War}_{\mathrm{ij}(\mathrm{t}-1)}$ is a dummy variable that equals 1 if states $i$ and $j$ are engaged in a war in year $\mathrm{t}-1$ (and 0 otherwise), ${ }^{27}$ and $\log \mathrm{z}_{\mathrm{ij}}$ is an error term. Note that in antilogarithmic form all dummy variables in this model take on values of $e$ (the base of the natural logarithms) and one; the natural logarithms of these variables, therefore, take on values of one and zero. Since it is generally assumed that these variables exert a lagged effect on the value of exports and in order to avoid problems of simultaneity, ${ }^{28}$ we assume a lag of one year in equation 1 for each variable. The log-linear specification of this model is used because it is consistent with many previous studies of trade that have used gravity models and because it has number of advantages relative to a linear specification (Leamer and Stern 1970).

Since we are interested in the relationship between alliances and trade at given points in time, as well as over time, equation 1 is estimated for a series of cross sections, beginning in 1905 . Our analysis begins with 1905 (year t) because complete data for all of the independent variables in equation 1 are not available prior to 1904 (year $t-1$ ). After 1905, the parameters in equation 1 are estimated for the first year of each subsequent ten-year interval. However, we do not estimate the model during World Wars I and II, since trade data are often not available for these years. Further, equation 1 is not estimated during the late 1940s because the occupation of Germany and Japan precluded both states from making autonomous decisions about trade policies or alliance partners. As a result, there are some cases in which the intervals are not ten years in length.

\section{Estimates of the Parameters}

Ordinary least squares estimates of the parameters in equation 1 are presented in Table 1 . In each regression, at least one outlier was identified. ${ }^{29}$ The results in Table 1 are estimated without these observations. However, it should be noted that very little difference exists between the results with these observations included and the results presented in Table $1 .^{30}$

These findings indicate that on average, our model explains over $80 \%$ of the variation in the value of exports and that the overall fit of the model differs little across the nine years that are analyzed. Our results also indicate that the regression coefficients of GNP, population, geographic distance, and war usually point in the expected directions and are statistically significant. First, the regression coefficient of log $Y_{i}$ is positive in nine cases and statistically significant in eight instances; and the regression coefficient of $\log Y_{j}$ is positive and statistically significant in all nine cases. Second, the regression coefficient of $\log P_{i}$ is negative in eight cases and statistically significant in seven instances; and the regression coefficient of log $P_{j}$ is negative in nine cases and statistically significant in eight instances. Third, the regression coefficient of $\log D_{i j}$ is negative in eight cases and statistically significant in five instances. Finally, the regression coefficient of log $\mathrm{War}_{\mathrm{ij}}$ is negative and statistically significant in one out of two cases.

These results also confirm the hypothesis that alliances are directly related to the value of exports. The regression coefficient of $\log \mathrm{BA}_{\mathrm{ij}}$ is positive in six out of nine cases and statistically significant in five instances; and the regression coefficient of $\log \mathrm{MA}_{\mathrm{ij}}$ is positive and statistically significant in six out of eight cases. Further, the mean of the nine regression coefficients of $\log \mathrm{BA}_{\mathrm{ij}}$ is about 1.09 and (assuming that these regression coefficients are statistically independent) the standard error of the mean is about $.15 .^{31}$ The mean of the eight regression coefficients of log $\mathrm{MA}_{\mathrm{ij}}$ is about .61, and the standard error of the mean is about $.16 .^{32}$ On average, therefore, the relationships between bilateral alliances and multilateral alliances, on the one hand, and bilateral trade on the other seem to be direct and statistically significant.

Moreover, the quantitative impacts of both bilateral and multilateral alliances on the predicted value of bilateral trade are substantial. Even if the mean of the regression coefficients of $\log \mathrm{BA}_{\mathrm{ij}}$ was two standard errors less than 1.09, a change from the absence of a bilateral alliance to the existence of such an alliance would more than double the predicted value of exports. ${ }^{33}$ And even if the mean of the regression 
TABLE 1

Regression of Exports on GNP, Population, Distance, Alliances, and War, 1905-85

\begin{tabular}{|c|c|c|c|c|c|c|c|c|c|}
\hline \multirow[b]{2}{*}{ PARAMETER } & \multicolumn{5}{|c|}{ PERIOD OF MULTIPOLARITY } & \multicolumn{4}{|c|}{ PERIOD OF BIPOLARITY } \\
\hline & 1905 & 1913 & 1920 & 1930 & 1938 & 1955 & 1965 & 1975 & 1985 \\
\hline Intercept & $\begin{array}{c}-4.57 \\
(7.88)\end{array}$ & $\begin{array}{c}-8.79 \\
(9.99)\end{array}$ & $\begin{array}{l}57.21^{\star \star \star} \\
(14.74)\end{array}$ & $\begin{array}{c}7.39 \\
(5.06)\end{array}$ & $\begin{array}{c}12.44^{\star} \\
(6.19)\end{array}$ & $\begin{array}{c}34.81^{\star \star \star} \\
(8.19)\end{array}$ & $\begin{array}{c}5.69 \\
(5.17)\end{array}$ & $\begin{array}{c}6.29 \\
(4.25)\end{array}$ & $\begin{array}{l}12.14^{\star \star} \\
(4.88)\end{array}$ \\
\hline $\log$ GNP $_{\mathbf{i}}$ & $\begin{array}{l}.95^{\star \star \star} \\
(.17)\end{array}$ & $\begin{array}{l}1.68^{\star \star \star} \\
(.23)\end{array}$ & $\begin{array}{l}2.78^{\star \star \star \star} \\
(.34)\end{array}$ & $\begin{array}{l}1.53^{\star \star \star} \\
(.14)\end{array}$ & $\begin{array}{l}1.67^{\star \star \star} \\
(.20)\end{array}$ & $\begin{array}{l}1.12^{\star \star \star} \\
(.26)\end{array}$ & $\begin{array}{c}.28 \\
(.26)\end{array}$ & $\begin{array}{l}.83^{\star \star \star} \\
(.20)\end{array}$ & $\begin{array}{l}.96^{\star \star \star} \\
(.32)\end{array}$ \\
\hline $\log \mathrm{GNP}_{\mathrm{j}}$ & $\begin{array}{l}1.10^{\star \star \star} \\
(.18)\end{array}$ & $\begin{array}{l}.90^{\star \star \star} \\
(.25)\end{array}$ & $\begin{array}{l}2.17^{\star \star \star} \\
(.27)\end{array}$ & $\begin{array}{l}1.25^{\star \star \star} \\
(.14)\end{array}$ & $\begin{array}{l}1.57^{\star \star \star} \\
(.22)\end{array}$ & $\begin{array}{l}.93^{\star \star \star} \\
(.25)\end{array}$ & $\begin{array}{l}.44^{\star *} \\
(.26)\end{array}$ & $\begin{array}{l}.55^{\star \star \star} \\
(.21)\end{array}$ & $\begin{array}{l}1.19^{\star \star \star} \\
(.32)\end{array}$ \\
\hline log Population & $\begin{array}{c}-.02 \\
(.33)\end{array}$ & $\begin{array}{c}-.95^{\star \star \star} \\
(.35)\end{array}$ & $\begin{array}{c}-4.10^{\star \star \star} \\
(.83)\end{array}$ & $\begin{array}{c}-1.21^{\star \star \star \star} \\
(.23)\end{array}$ & $\begin{array}{c}-1.68^{\star \star \star} \\
(.34)\end{array}$ & $\begin{array}{c}-1.88^{\star \star \star} \\
(.49)\end{array}$ & $\begin{array}{l}.14 \\
(.39)\end{array}$ & $\begin{array}{c}-.68^{\star \star \star} \\
(.26)\end{array}$ & $\begin{array}{c}-1.13^{\star \star \star} \\
(.42)\end{array}$ \\
\hline log Population & $\begin{array}{c}-1.21^{\star \star \star} \\
(.27)\end{array}$ & $\begin{array}{c}-.92^{\star \star \star} \\
(.31)\end{array}$ & $\begin{array}{c}-4.83^{\star \star \star} \\
(.59)\end{array}$ & $\begin{array}{c}-1.74^{\star \star \star} \\
(.23)\end{array}$ & $\begin{array}{c}-2.27^{\star \star \star} \\
(.32)\end{array}$ & $\begin{array}{c}-1.82^{\star \star \star} \\
(.49)\end{array}$ & $\begin{array}{c}-.38 \\
(.39)\end{array}$ & $\begin{array}{c}-.45^{\star \star} \\
(.25)\end{array}$ & $\begin{array}{c}-1.42^{\star \star \star *} \\
(.40)\end{array}$ \\
\hline $\log$ Distance $_{i j}$ & $\begin{array}{c}-.33^{\star \star \star} \\
(.09)\end{array}$ & $\begin{array}{l}-.06 \\
(.10)\end{array}$ & $\begin{array}{l}.27 \\
(.13)\end{array}$ & $\begin{array}{c}-.35^{\star \star \star} \\
(.06)\end{array}$ & $\begin{array}{r}-.06 \\
(.09)\end{array}$ & $\begin{array}{c}-.01 \\
(.09)\end{array}$ & $\begin{array}{c}-.12^{\star \star} \\
(.06)\end{array}$ & $\begin{array}{c}-.23^{\star \star \star} \\
(.05)\end{array}$ & $\begin{array}{c}-.28^{\star \star \star \star} \\
(.07)\end{array}$ \\
\hline $\log$ Bilat. alliance $e_{i j}$ & $\begin{array}{c}-.37 \\
(.31)\end{array}$ & $\begin{array}{c}-.57 \\
(.36)\end{array}$ & $\begin{array}{l}.20 \\
(.77)\end{array}$ & $\begin{array}{l}1.04^{\star \star \star \star} \\
(.42)\end{array}$ & $\begin{array}{r}-.30 \\
(.40)\end{array}$ & $\begin{array}{l}3.02^{\star \star \star} \\
(.55)\end{array}$ & $\begin{array}{l}2.58^{\star \star \star} \\
(.39)\end{array}$ & $\begin{array}{l}2.07^{\star \star \star} \\
(.32)\end{array}$ & $\begin{array}{l}2.10^{\star \star \star} \\
(.43)\end{array}$ \\
\hline $\log$ Multilat. alliance $e_{i j}$ & $\begin{array}{c}-.61 \\
(.55)\end{array}$ & $\begin{array}{r}-.31 \\
(.72)\end{array}$ & $\begin{array}{l}.96^{\star \star \star} \\
(.39)\end{array}$ & $-a$ & $\begin{array}{l}.48^{*} \\
(.35)\end{array}$ & $\begin{array}{l}.86^{\star \star} \\
(.46)\end{array}$ & $\begin{array}{l}1.65^{\star \star \star} \\
(.33)\end{array}$ & $\begin{array}{l}.99^{\star \star \star} \\
(.18)\end{array}$ & $\begin{array}{l}.84^{\star \star \star} \\
(.26)\end{array}$ \\
\hline $\log W a r_{i j}$ & $\begin{array}{c}-7.12^{\star \star \star} \\
(.61)\end{array}$ & $-b$ & $\begin{array}{l}1.55 \\
(.72)\end{array}$ & $-^{b}$ & $-b$ & $-{ }^{b}$ & $-b$ & $-b$ & $-b$ \\
\hline $\begin{array}{l}\text { Adjusted } R^{2} \\
N\end{array}$ & $\begin{array}{l}.92 \\
39\end{array}$ & $\begin{array}{l}.71 \\
39\end{array}$ & $\begin{array}{r}.83 \\
37^{c}\end{array}$ & $\begin{array}{l}.86 \\
40\end{array}$ & $\begin{array}{l}.80 \\
37^{d}\end{array}$ & $\begin{array}{l}.78 \\
41\end{array}$ & $\begin{array}{l}.82 \\
40\end{array}$ & $\begin{array}{l}.82 \\
41\end{array}$ & $\begin{array}{l}.80 \\
41\end{array}$ \\
\hline \multicolumn{10}{|c|}{ 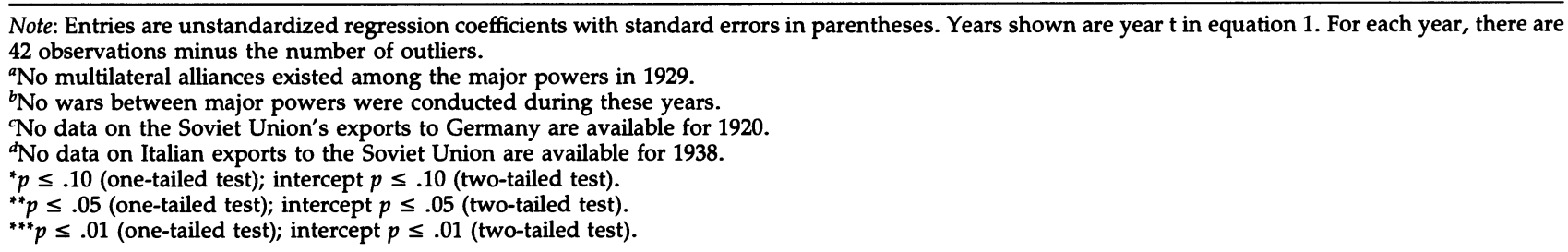 } \\
\hline
\end{tabular}

coefficients of $\log \mathrm{MA}_{\mathrm{ij}}$ was two standard errors less than .61 , a change from the absence of a multilateral alliance to the existence of such an alliance would increase the predicted value of exports by more than one-third. ${ }^{34}$

As expected, the system's structure influences the strength and the magnitude of the effect of alliances on trade. The means of the regression coefficients of $\log \mathrm{BA}_{\mathrm{ij}}$ and $\log \mathrm{MA}_{\mathrm{ij}}$ have been substantially larger during periods of bipolarity than during periods of multipolarity; and the differences between these means are statistically significant (for $\log \mathrm{BA}_{\mathrm{ij}}, \mathrm{t}=$ 6.26, $p<.005$; for $\left.\log \mathrm{MA}_{\mathrm{ij}}, \mathrm{t}=2.34, p<.05\right)$. Thus, our results indicate that on average, the magnitude of the effects of alliances on trade has been considerably more pronounced during bipolar periods than during multipolar periods.

There is also some support for our hypothesis that bilateral alliances exert larger effects on trade than multilateral alliances, although the evidence is weaker than expected. When all years in Tables 1 are considered, the mean of the regression coefficients of $\log \mathrm{BA}_{\mathrm{ij}}$ is almost twice as large as the mean of the regression coefficients of $\log \mathrm{MA}_{\mathrm{ij}}$, but the difference between these means is not statistically significant.
When only bipolar periods are examined, the mean of the regression coefficients of $\log \mathrm{BA}_{\mathrm{ij}}$ is substantially larger than the mean of the regression coefficients of $\log \mathrm{MA}_{\mathrm{ij}}$; and the difference between these means is statistically significant $(t=4.50, p<.005)$. But when only multipolar periods are analyzed, the mean of the regression coefficients of $\log \mathrm{MA}_{\mathrm{ij}}$ is somewhat larger than the mean of the regression coefficients of log $\mathrm{BA}_{\mathrm{ij}}$; and, although the difference between these means is not statistically significant, this result is clearly at odds with our hypothesis. Hence, the extent to which our hypothesis concerning the effects of different types of alliances on trade is supported seems to depend in large measure on system structure.

\section{THE ROBUSTNESS OF THE RESULTS}

In addition to estimating the effects of alliances on trade, it is also important to analyze the robustness of the results in Table 1 . To this end, we address two issues. First, does the composition of the sample of states affect the results? More specifically, does the fact that we include the Soviet Union in our sample 
TABLE 2

Regression of Exports on Per Capita GNP, Distance, and Alliances, Excluding the Soviet Union, 1905-1985

\begin{tabular}{|c|c|c|c|c|c|c|c|c|}
\hline \multirow[b]{2}{*}{ PARAMETER } & \multicolumn{4}{|c|}{ PERIOD OF MULTIPOLARITY } & \multicolumn{4}{|c|}{ PERIOD OF BIPOLARITY } \\
\hline & 1905 & 1913 & 1920 & 1938 & 1955 & 1965 & 1975 & 1985 \\
\hline Intercept & $\begin{array}{l}9.57^{\star \star \star} \\
(2.54)\end{array}$ & $\begin{array}{c}3.60 \\
(3.46)\end{array}$ & $\begin{array}{c}2.68 \\
(2.95)\end{array}$ & $\begin{array}{c}3.17 \\
(3.05)\end{array}$ & $\begin{array}{l}10.51^{\star \star \star} \\
(1.85)\end{array}$ & $\begin{array}{l}8.73^{\star \star} \\
(3.48)\end{array}$ & $\begin{array}{l}8.33^{\star \star \star} \\
(2.79)\end{array}$ & $\begin{array}{c}7.78^{\star} \\
(4.27)\end{array}$ \\
\hline log Per capita GNP $_{i}$ & $\begin{array}{l}1.12^{\star \star \star} \\
(.23)\end{array}$ & $\begin{array}{l}1.76^{\star \star \star} \\
(.30)\end{array}$ & $\begin{array}{l}1.88^{\star \star \star} \\
(.29)\end{array}$ & $\begin{array}{l}1.41^{\star \star \star} \\
(.26)\end{array}$ & $\begin{array}{l}.80^{\star \star \star} \\
(.21)\end{array}$ & $\begin{array}{l}.79^{\star \star \star} \\
(.31)\end{array}$ & $\begin{array}{l}.90^{\star \star \star} \\
(.21)\end{array}$ & $\begin{array}{l}.69^{\star \star} \\
(.30)\end{array}$ \\
\hline log Per capita GNP $_{\mathrm{j}}$ & $\begin{array}{l}.96^{\star \star \star} \\
(.23)\end{array}$ & $\begin{array}{l}.69^{\star \star \star} \\
(.32)\end{array}$ & $\begin{array}{l}.94^{\star \star \star} \\
(.28)\end{array}$ & $\begin{array}{l}1.36^{\star \star *} \\
(.26)\end{array}$ & $\begin{array}{l}.51^{\star * *} \\
(.20)\end{array}$ & $\begin{array}{l}.82^{\star \star \star} \\
(.30)\end{array}$ & $\begin{array}{l}.78^{\star \star \star} \\
(.21)\end{array}$ & $\begin{array}{l}1.15^{\star \star \star} \\
(.30)\end{array}$ \\
\hline $\log$ Distance $_{\mathrm{ij}}$ & $\begin{array}{c}-.26^{\star \star} \\
(.11)\end{array}$ & $\begin{array}{c}.06 \\
(.14)\end{array}$ & $\begin{array}{c}-.21^{\star \star} \\
(.10)\end{array}$ & $\begin{array}{c}-.18^{\star \star} \\
(.10)\end{array}$ & $\begin{array}{r}-.14^{\star} \\
(.10)\end{array}$ & $\begin{array}{r}-.17^{\star} \\
(.11)\end{array}$ & $\begin{array}{c}-.21^{\star \star \star \star} \\
(.06)\end{array}$ & $\begin{array}{c}-.32^{\star \star *} \\
(.09)\end{array}$ \\
\hline log Bilat. alliance $e_{i j}$ & $\begin{array}{c}-.41 \\
(.39)\end{array}$ & $\begin{array}{c}-.11 \\
(.42)\end{array}$ & $\begin{array}{c}.58 \\
(.66)\end{array}$ & $\begin{array}{c}-.21 \\
(.62)\end{array}$ & $\begin{array}{l}2.36^{\star \star \star} \\
(.49)\end{array}$ & $\begin{array}{l}2.41^{\star \star \star} \\
(.51)\end{array}$ & $\begin{array}{l}2.18^{\star \star \star} \\
(.32)\end{array}$ & $\begin{array}{l}1.92^{\star \star \star} \\
(.44)\end{array}$ \\
\hline log Multilat. alliance ${ }_{i j}$ & $\begin{array}{c}-.61 \\
(.63)\end{array}$ & $\begin{array}{c}-.12 \\
(.75)\end{array}$ & $\begin{array}{l}1.06^{\star *} \\
(.35)\end{array}$ & $\begin{array}{c}.33 \\
(.41)\end{array}$ & $\begin{array}{l}1.31^{\star \star \star} \\
(.53)\end{array}$ & $\begin{array}{l}.93^{*} \\
(.55)\end{array}$ & $\begin{array}{l}.97^{\star \star \star} \\
(.25)\end{array}$ & $\begin{array}{l}.80^{\star \star \star} \\
(.31)\end{array}$ \\
\hline Adjusted $\mathrm{R}^{2}$ & .75 & .63 & .74 & .78 & .87 & .80 & .85 & .81 \\
\hline $\mathbf{N}$ & 28 & 28 & 28 & 28 & 29 & 30 & 28 & 28 \\
\hline
\end{tabular}

enhance the influence of alliances on trade? Second, does the omission of certain variables that might be expected to influence both alliance patterns and trade flows account for the observed relationship between alliances and bilateral commerce?

\section{Estimates of the Parameters Excluding the Soviet Union}

It is possible that including the Soviet Union in our sample may have exaggerated the impact of alliances on trade (in Table 1). The Soviet Union had both a command and a relatively autarkic economy during most of the twentieth century. It also concluded few alliances with other major powers in our sample after World War I. Thus, the strength of the observed relationship between alliances and trade might be due to the composition of our sample. In order to determine whether this is the case, ordinary least squares estimates of the parameters in equation 1 were obtained for those dyads that did not involve the Soviet Union.

These results (and auxiliary regressions based on these results) indicated that unlike our findings in Table 1, there was often considerable multicollinearity among $\log Y_{i}, \log Y_{j}, \log P_{i}$, and $\log P_{j}$ when dyads involving the Soviet Union were excluded from our analysis. One solution to this type of problem is to combine some of the explanatory variables (Fox 1991, 15-16). We, therefore, focus on the effects of the nominal per capita GNP (which is expressed as $\mathrm{Y} / \mathrm{P}$ ) of both the importer and the exporter, as well as distance and alliances, on nominal exports. This specification of our model is as follows:

$$
\begin{aligned}
\log \mathrm{X}_{\mathrm{ij}(\mathrm{t})} & =\log \mathrm{A}+\mathrm{B}_{1} \log (\mathrm{Y} / \mathrm{P})_{\mathrm{i}(\mathrm{t}-1)}+\mathrm{B}_{2} \log (\mathrm{Y} / \mathrm{P})_{\mathrm{j}(\mathrm{t}-1)} \\
& +\mathrm{B}_{3} \log \mathrm{D}_{\mathrm{ij}(\mathrm{t}-1)}+\mathrm{B}_{4} \log \mathrm{B} \mathrm{A}_{\mathrm{ij}(\mathrm{t}-1)} \\
& +\mathrm{B}_{5} \log \mathrm{MA}_{\mathrm{ij}(\mathrm{t}-1)}+\log \mathrm{z}_{\mathrm{ij}},
\end{aligned}
$$

where $\log (\mathrm{Y} / \mathrm{P})_{\mathrm{i}(\mathrm{t}-1)}$ is the natural logarithm of the nominal per capita GNP of state $i$ in year $t-1, \log$ $(\mathrm{Y} / \mathrm{P})_{\mathrm{j}(\mathrm{t}-1)}$ is the natural logarithm of the nominal per capita GNP of state $\mathrm{j}$ in year $\mathrm{t}-1$, and the nominal per capita GNP of both states $i$ and $j$ is expected to be directly related to the nominal value of exports from $i$ to $\mathrm{j}$ (Frankel 1992, Linnemann 1966). Since each of the wars we considered in our earlier analysis involved the Soviet Union, War $_{\mathrm{ij}}$ is not included in this model. Further, because all alliances in 1929 involved the Soviet Union, it was not possible to estimate the effects of alliances on trade for this year.

Ordinary least squares estimates of the parameters of equation 2 are presented in Table 2 (with outliers deleted). ${ }^{35}$ These results indicate that on average, our model continues to explain about $80 \%$ of the variation in exports and that the signs of the regression coefficients of per capita GNP and geographic distance are in the expected directions. In every case, the regression coefficients of $\log (\mathrm{Y} / \mathrm{P})_{\mathrm{i}}$ and $\log (\mathrm{Y} / \mathrm{P})_{\mathrm{j}}$ are positive and statistically significant; and the regression coefficient of $\log D_{i j}$ is negative and statistically significant in seven out of eight instances.

Of particular interest is the fact that the effects of both bilateral and multilateral alliances on bilateral trade are much the same, regardless of whether or not the Soviet Union is excluded from our sample of states. In no case does the sign of the regression coefficient of either $\log \mathrm{BA}_{\mathrm{ij}}$ or $\log \mathrm{MA}_{\mathrm{ij}}$ in Table 1 
change when the Soviet Union is deleted; and in only one case $\left(\log \mathrm{MA}_{\mathrm{ij}}\right.$ in 1938) does the level of statistical significance of the regression coefficient of either log $\mathrm{BA}_{\mathrm{ij}}$ or $\log \mathrm{MA}_{\mathrm{ij}}$ in Table 1 change when the composition of our sample of states is altered. Moreover, the means of the regression coefficients of both $\log \mathrm{BA}_{\mathrm{ij}}$ (1.09) and $\log \mathrm{MA}_{\mathrm{ij}}(.58)$ are virtually identical to those based on the results in Table 1 .

On average, therefore, the relationships between both bilateral and multilateral alliances and bilateral trade continue to be direct and statistically significant. It should also be noted that on average, the magnitude of the effects of bilateral alliances on trade continues to be larger than that of multilateral alliances and that on average, the magnitude of the effects of both bilateral and multilateral alliances on bilateral trade continues to be significantly larger during periods of bipolarity than during periods of multipolarity.

\section{The Effects of Omitted Variables}

We now turn to the issue of whether our results in Table 1 are robust with respect to the inclusion of variables that are omitted from equation 1 and that might account for the observed relationship between alliances and trade. First, as we have noted, many analysts have concluded that PTAs have promoted trade among their members. Further, since many of these arrangements have been embedded in alliances, it may be that PTAs are responsible for the observed relationship between alliances and trade.

In order to test this hypothesis, we conducted two separate analyses. Initially, we included a dummy variable in equation 1 that equalled 1 if states $i$ and $j$ were members of the European Economic Community in year $t-1$, and 0 otherwise. Next, we included a dummy variable in equation 1 that equalled 1 if states $i$ and $j$ were members of the GATT in year $t-$ 1 , and 0 otherwise. In each case, we analyzed 1965, 1975, and 1985; and both analyses yielded quite similar findings. ${ }^{36}$ In each analysis, the regression coefficient of the dummy variable was positive in all three cases (i.e., more trade has been conducted between states that were PTA members than between states that were not). But, in each case, only one regression coefficient was statistically significant; and the inclusion of this variable did not have a substantial effect on either the size or the level of statistical significance of any of the remaining regression coefficients in equation 1.

Second, in addition to wars, military disputes that do not escalate into wars may also influence bilateral trade relations. Further, the existence of military disputes may influence alliance patterns. In order to test whether military disputes account for the observed relationship between alliances and trade, we included in equation 1 a dummy variable that equalled 1 if states $i$ and $j$ were involved in a militarized dispute in year $t-1$, and 0 otherwise. Among the years listed in Table 1 , four were marked by military disputes, based on data developed by Goch- man and Maoz (1984) and recently updated by the Correlates of War Project. Our findings indicated that the regression coefficient of this variable tended to be negative (i.e., the existence of a dispute involving states $i$ and $j$ tended to depress trade between them). But in no case was it statistically significant, nor did its inclusion in equation 1 substantially change either the size or the level of statistical significance of any of the remaining regression coefficients in our model.

Third, whether or not the states in our sample are democratic polities may account for the observed relationship between alliances and bilateral trade flows. Democratic states might, for example, trade more freely with each other than do either nondemocracies with democracies or nondemocracies with each other. This might occur because democratic states typically have relatively free market economies. Recent research also suggests that democracies have exhibited a disproportionate tendency to ally with one another during portions of the twentieth century (Siverson and Emmons 1991).

In order to determine whether the observed relationship between alliances and trade is due to regime type, a dummy variable was included in equation 1 that equalled 1 if both states $i$ and $j$ were democracies in year $t-1$, and 0 otherwise, based on Doyle's (1986) data. Our results indicated that the sign of this regression coefficient varied substantially from year to year and that it was statistically significant in only one case. Moreover, the size and level of statistical significance of the remaining regression coefficients in equation 1 continued to be much the same as in Table 1.

Clearly, we are not suggesting that PTAs, military disputes, and regime type do not influence bilateral trade flows at all. But these factors do not seem to account for the observed relationship between alliances and trade among major powers during the twentieth century. Nor does the composition of the sample: our findings are also quite robust with respect to whether the Soviet Union is included in the analysis. Thus, while tentative, our results indicate that bilateral trade flows between major powers tend to be considerably higher when they are allies than when they are not.

\section{CONCLUSION}

We have argued that a free-trade policy can be suboptimal for states in an anarchic international system. Under some conditions, an effort to induce trade to follow the flag can be welfare-enhancing. The results of our empirical analysis support the implications of our argument about the relationship between alliances and trade. They show that alliances exert a direct, statistically significant, and large effect on bilateral trade flows. They also show that the effects of alliances vary. Bilateral alliances sometimes influence trade flows more strongly than do multilateral alliances; and alliances embedded in bipolar systems 
have stronger effects upon trade than do their counterparts in multipolar systems.

The argument we develop here also suggests that there may be other sources of cross-alliance variation that our empirical analysis could not detect. One plausible source is differences across alliances with respect to the gains that would accrue from free trade and its associated externalities. According to the tenets of the Heckscher-Ohlin-Samuelson model of international trade, for example, gains from trade and differences in relative factor endowments are directly related. Thus, this model implies that allies with very different factor endowments will confront stronger incentives to trade freely with each other than will allies with more similar endowments.

The weight a state assigns to its ally will also affect the magnitude of the security externality that free trade generates. Cross-alliance variations in $w_{\mathrm{ij}}$ might occur, for example, because of differences in the probability of war, the technology of weapons production, or the need (if any) for an ex ante coordination of forces. In addition, the magnitude of the external effects of trade depends upon the transaction costs of opening borders to trade. These costs might vary as a consequence, for example, of whether an alliance has been given formal institutional expression (Keohane 1984; Snidal 1985).

Because of these and other possible sources of cross-alliance variation, it is clear that we have not offered an exhaustive analysis of the impact of alliances on trade. Nonetheless, we have established the conditions under which it makes sense for states to attempt to tie trade to the flag. In addition, we show that alliances have influenced bilateral trade flows not only after, but also before, 1945. In doing so, we suggest that the end of the Cold War will precipitate changes in the play of power politics both in the political-military sphere and in the pattern of international trade.

\section{Notes}

The alphabet determined the ordering of the authors' names. For their comments on earlier versions of this paper, we are grateful to Charles Cameron, Benjamin J. Cohen, Youssef Cohen, John A. C. Conybeare, Stephen M. Goldfeld, Robert O. Keohane, Timothy J. McKeown, Arvid Lukauskas, J. David Richardson, Robert Powell, and Beth V. Yarbrough. We are also grateful to Rachel Bronson, Matthias Kaelberer, and Hank Torbert for research assistance. In conducting this research, Gowa was assisted by awards from the Social Science Research Council of a MacArthur Foundation Fellowship in International Security and the Peter B. Lewis Family Fund and the Boesky Family Fund of the Center for International Studies at Princeton University; Mansfield was assisted by a grant from the Columbia University Council for Research in the Social Sciences.

1. Disagreement continues about the source of this preference ranking, however. Some attribute it to the public good character of international trade (e.g., Kindleberger 1973); others attribute it to the ability of states to exercise monopoly or monopsony power in world markets (Conybeare 1984). Still others contend that the trade game can be a coordination game (Snidal 1985).
2. Our argument and analysis are limited to the influence on trade of system-level variables. For incisive analyses of the domestic determinants of tariffs, see Frieden 1988; Magee, Brock, and Young 1989; and Ruggie 1982.

3. The voluminous literature on economic statecraft at the microeconomic level that now exists partly explains our decision to focus this analysis at the macroeconomic level. The decision, however, was also the product of the almost insuperable obstacles that confront any attempts at embargo, probably the most common form of microeconomic statecraft. For a good discussion, see Bayard, Pelzman, and Lopez 1983.

4. Externalities are uncompensated costs or benefits that an agent inflicts or confers on third parties.

5. This divergence arises because those whose actions generate externalities have no incentive to take these external effects into account. Thus, if an individual's actions produce diseconomies, for example, he will engage in them to a socially suboptimal extent. For a more detailed explanation, see Yeager and Tureck 1983/84, 661.

6. We use tariffs here as a substitute for several forms of government intervention in trade. Because of constraints imposed by the General Agreement on Tariffs and Trade, government intervention in trade now usually takes the form of nontariff barriers. As long as the home country captures the scarcity rents that accrue from trade barriers, the form in which intervention occurs does not affect the argument presented here.

7. The theory of the second best applies to most national security arguments for government intervention in trade: the latter usually imposes higher costs on national welfare than do policies that target the distortion directly. For example, if production in an import-competing industry is judged inadequate on national security grounds, the Pareto-optimal policy is a production subsidy (Corden 1986). The general principle, as Deardorff and Stern observe, "is that trade intervention, by introducing two distortions rather than one, may succeed in solving one problem but only at the same time that it causes another. Trade policy is like doing acupuncture with a fork: no matter how carefully you insert one prong, the other is likely to do damage" $(1987,39)$.

8. That is, a player is better off defecting regardless of what the other player does.

9. If incomplete information of a specific kind exists in a finite prisoner's dilemma game, however, it is possible for mutual cooperation to emerge on at least some plays of the game. See Kreps et al. 1982.

10. As the Folk theorem states, if the horizon is infinite and the actors are very patient, any individually rational outcome can be sustained (Fudenberg and Maskin 1986).

11 . In a context in which deviations are perfectly observable, maximal punishment makes sense, because it never occurs on the equilibrium path. It is, therefore, costless (Tirole 1988, 252). Moreover, unlike Tit for Tat, a grim strategy is subgame perfect (i.e., it is rational for the players to follow the specified strategies if any defection occurs) (Rasmusen 1989, 91).

It is not, however, renegotiation-proof (i.e., if one player defects and the players have the opportunity to renegotiate, they will abandon the punishment strategy in favor of one that confers higher payoffs.) A Pareto-perfect or weakly renegotiation-proof strategy is a "penance" strategy: begin with cooperation; if a deviation occurs, the deviator cooperates and the other player defects; the players then revert to cooperation (Fudenberg and Tirole 1991, 179-82). We use a grim strategy here for two reasons: (1) it is more accessible; and more importantly, (2) our results do not change if a penance strategy is used.

12. The discount factor, $\delta$, is "the value in present payoff units of one payoff unit to be received one period from the present." It reflects both the rate of time preference, $\rho$, and the probability that the game will end, $\theta$. The discount factor is $(1-\theta) /(1+\rho)$ (Rasmusen 1989, 90). Thus, the discounted sum of an infinite series of payoffs, $x$, received at the beginning of each period is: $(x)(1-\theta) /(1+\rho)$.

13. Even though much progress has been made, com- 
pletely free trade remains elusive. Nonetheless, the GATT has clearly facilitated the process of lowering trade barriers among its member countries. Yarbrough and Yarbrough (1992) argue, however, that it is not grim strategies but third-party (i.e., U.S.) enforcement that has deterred states from defecting from GATT agreements. For a dramatic comparison of the postwar and interwar periods, see Oye 1992.

14. Adapted from Snidal 1991.

15. The game will remain a prisoner's dilemma as long as $0 \leq w<1$.

16. We distinguish bipolar and multipolar systems here in terms of the number of great powers that exist in any given system (Snyder and Diesing 1977, 419-20; Waltz 1979). We do not mean to imply, however, that polarity is either the only, or necessarily the most important, aspect of the distribution of power. Other aspects, especially the concentration of power, might also influence the relationship between alliances and trade (Mansfield n.d.).

17. Empirical analyses support this assertion. See, e.g., Duncan and Siverson 1982.

18. It should be noted that Pollins's (1989a, 1989b) analyses take account of the effects of alliances on trade to the extent that a "major strategic alliance" is considered a cooperative "event" in the data that he uses (see Azar 1980; Polachek $1980,58, n .5)$. However, since Pollins's objective is to assess the effects of aggregate levels of conflict and cooperation on trade, he does not disaggregate the influence of various types of cooperative events, such as alliances.

19. Of course, trade barriers and trade flows need not always move in tandem. Tariffs, for example, may not be completely endogenized if demand is infinitely inelastic with respect to price. In addition, the 1970 s witnessed the expansion of both trade barriers and trade flows. However, once we control for other determinants of trade, we would expect these variables to be directly related; and this approach should therefore provide a useful first cut at the problem.

20. For the period after World War II, we analyze West Germany; for the period before 1917, Russia. In order to simplify the presentation, however, we refer only to "Germany" and "the Soviet Union" in the text.

21. Small countries are excluded from this study, in addition, because they would not ordinarily be expected to be able to influence their terms of trade.

22. For the period from 1938 to 1985 , all data on exports are taken from the International Monetary Fund's Direction of Trade for the years 1950,1956, 1966, 1976, and 1986. For the period from 1905 to 1930, data are taken from Cacciapuoti 1928, 87-90; Clarke and Matko 1983, 62-73; France, Bureau de la Statistique Generale 1923, 236; League of Nations 1926, vol 1, 218-39 and 1933, 328-48; Liesner 1989; Mitchell 1980, 1982, 1983; U.S. Bureau of the Census 1915, 330-37, 355-56; and U.S. Department of Commerce 1934-and also from the Commerce Department's Foreign Commerce and Navigation of the United States for 1914, 1921, and 1931 (pp. 7-8, 5-12, and 6-14, respectively) and the Japanese Finance Department's Annual Return of the Foreign Trade of the Empire of Japan for the years 1905 and 1920. In those cases where exports are not denominated in U.S. dollars, exchange rates are taken from Bidwell 1970; Liesner 1989, 54-55; and the Treasury Department's Circulars for the years 1904-5, 1912-13, and 1919-20.

It should also be pointed out that in some cases, exports by state $i$ to state $j$ are not available. However, in these cases, it is usually possible to find data on imports by $j$ from $i$. Since these values should be equal, we convert imports in j's currency into U.S. dollars and use these data as measures of exports from $i$ to $j$. When we do so, we should adjust the data to reflect the fact that the value of imports reported sometimes includes transportation costs. We do not do so, however, because our sources do not uniformly report on whether or not import data are net of transportation costs.

23. Data on nominal GNP for the period from 1904 to 1929 are taken from Gregory 1982; Liesner 1989; and Mitchell 1980, 1982,1983 . In certain cases, reliable data on Soviet and French GNP are not available. In these cases, GNP is estimated using data in Bairoch 1976; Gregory 1982; and Mitchell 1980. Data on nominal GNP and exchange rates for the period from 1937 to 1984 are taken from the United Nations' Yearbook of National Account Statistics for the years 1948, 1955, 1965, 1975, and 1985. For exchange rate data covering the period prior to 1937 , see n. 22.

24. All data on national population are taken from Correlates of War Project 1991. It should be noted that since no data on West German population are available for 1954, we use data for 1955.

25. Data on geographical distances are found in Fitzpatrick and Modlin 1986 and the U.S. Hydrographic Office's Table of Distances in Nautical and Statute Miles for 1912 and 1936 and Distance between Ports for 1965 and 1989. For each pair of states, the shortest distance between ports or rail centers was used to measure the distance between states $i$ and $j$.

26. Throughout this study, Small and Singer's (1969) data on alliances are used. We consider any defense pact, neutrality or nonaggression pact, or entente that is listed by Small and Singer to be an alliance. Because the purpose of Small and Singer's study was to explain war, they excluded all wartime alliances from their data. As they themselves observed, however, if their data are used for other purposes, the list of alliances should be amended correspondingly (p. 262). Thus, we also include as allies any states that fought on the same side of any interstate war, as listed by either Levy (1983) or Small and Singer (1982). For present purposes, this results in the inclusion of one multilateral alliance among Great Britain, France, Japan, and the United States in 1919, when these states participated in the Russian Civil War (Levy 1983). We also code the Japanese-United States Security Treaty (195160 ) and the subsequent Treaty of Mutual Cooperation and Security between these states (1960-present) as alliances. Among other things, these treaties called for the United States to come to the aid of Japan in the event that it was attacked (see Grenville 1974, 270, 286-87). As a result, they served much the same purpose as an alliance.

27 . In this study, any war that is listed by either Levy (1983) or Small and Singer (1982) is analyzed. It might be expected that wars would exert a contemporaneous, as well as a lagged, effect on trade. Since both of the wars considered in this study were being waged in year $t$, as well as year $t-1$, any contemporaneous effect these wars might have on trade will be captured by our model. Further, it should be noted that only one war (the Changkufeng War, 1938) would be added to our list of wars if we measured this variable in year $t$, rather than year $t-1$.

28. While this strategy avoids potential problems of simultaneity, it is, of course, possible that the relationship between trade and alliances is multidirectional. Although it would also be useful to assess the effect of trade on alliance patterns, developing an adequate model of alliances is clearly beyond our scope here.

29. Outliers were identified based on the value of studentized residuals (see Fox 1991, 25-29; Maddala 1988, 412-17). Space limitations preclude us from presenting the results here both with and without outliers. The complete set of results for all the analyses in this paper can be found in Gowa (n.d.).

30. In regression analyses of this sort, it is important to ensure that the errors are not heteroscedastic. The results of White tests yielded no evidence of heteroscedasticity for any of estimates reported in this study. See Maddala 1988, 162-63; White 1980.

31. Assuming that this condition obtains, the standard error of the mean $(s(\bar{x}))$ of the regression coefficients of log $B A_{i j}$ is estimated by

$$
s(\bar{x})=\sqrt{\frac{\sum_{i=1}^{n} s_{i}^{2}}{n^{2}}},
$$

where $s_{i}^{2}$ is the estimated variance of the $i^{\text {th }}$ regression coefficient of $\log B A_{i j}$ and $n$ is the number of cross sections for which this regression coefficient is estimated. 
32. See n. 31

33. In antilogarithmic form, equation 1 can be expressed as

$$
\begin{gathered}
X_{i j(t)}=A Y_{i(t-1)}^{B 1} Y_{j(t-1)}^{B 2} P_{i(t-1)}^{B 3} P_{j(t-1)}^{B 4} D_{i j(t-1)}^{B 5} \\
B A_{i j(t-1)}^{B 6} M_{i j(t-1)}^{B 8} W_{i j(t-1)}^{B 8} Z_{i j},
\end{gathered}
$$

where $\mathrm{BA}_{\mathrm{ij}(\mathrm{t}-1)}$ is a dummy variable that equals $\mathrm{e}$ (the base of the natural logarithms) if a bilateral alliance exists between states $i$ and $j$ in year $t-1$, and 1 otherwise. It is clear that if $\mathrm{BA}_{\mathrm{ij}(\mathrm{t}-1)}=1\left(\right.$ and $\left.\log \mathrm{BA}_{\mathrm{ij}(\mathrm{t}-1)}=0\right)$, then

$$
\begin{aligned}
X_{i j(t)}= & A Y_{i(t-1)}^{B 1} Y_{j(t-1)}^{B 2} P_{i(t-1)}^{B 3} P_{j(t-1)}^{B 4} D_{i j(t-1)}^{B 5} \\
& 1^{B 6} M_{i j(t-1)}^{B 7} W a r_{i j(t-1)}^{B 8} Z_{i j} .
\end{aligned}
$$

On the other hand, if $\mathrm{BA}_{\mathrm{ij}(\mathrm{t}-1)}=\mathrm{e}\left(\right.$ and $\left.\log \mathrm{BA}_{\mathrm{ij}(\mathrm{t}-1)}=1\right)$, then

$$
\begin{aligned}
X_{i j(t)}= & A Y_{i(t-1)}^{B 1} Y_{j(t-1)}^{B 2} P_{i(t-1)}^{B 3} P_{j(t-1)}^{B 4} D_{i j(t-1)}^{B 5} \\
& e^{B 6} M_{i j(t-1)}^{B 7} W \operatorname{Wr}_{i j(t-1)}^{B 8} Z_{i j} .
\end{aligned}
$$

As a result, the proportional increase in the predicted value of exports by state $i$ if there exists a bilateral alliance between states $i$ and $j$ (rather than no bilateral alliance between them) is equal to $e^{B 6}$ minus one. Since the mean of $B_{6}$ in Table 1 is about 1.09 and the standard error of the mean is about .15, if the mean was two standard errors less than 1.09 , it would equal .79 . And since $e^{.79}=2.20$, the average effect of the change from the absence of a bilateral alliance between states $i$ and $j$ to the existence of such an alliance is to increase the predicted value of exports from $i$ to $j$ by $120 \%$, when the remaining variables in the model are held constant.

34. See n. 33. This is the case, since $e^{.29}=1.34$.

35. See n. 29.

36. For two reasons, we do not examine the effects of the GATT in 1955: (1) all of the states in our sample that were GATT members in 1954 (year $t$ - 1) were also NATO members; and (2) for balance-of-payments reasons, several European members of the GATT had imposed quotas on imports from the dollar area.

\section{References}

Aitken, Norman D. 1973. "The Effect of the EEC and EFTA on European Trade: A Temporal and Cross-Section Analysis." American Economic Review 63:881-92.

Anderson, James E. 1979. "A Theoretical Foundation for the Gravity Equation." American Economic Review 69:106-16.

Azar, Edward. 1980. "The Conflict and Peace Data Bank (COPDAB) Project." Journal of Conflict Resolution 24:143-52.

Bairoch, Paul. 1976. "Europe's Gross National Product, 1800 1975." Journal of European Economic History 5:273-340.

Baldwin, David A. 1985. Economic Statecraft. Princeton: Princeton University Press.

Bayard, Thomas O., Joseph Pelzman, and Jorge Perez Lopez. 1983. "Stakes and Risks in Economic Sanctions." World Economy 6:73-88.

Bidwell, R. L. 1970. Currency Conversion Tables: A Hundred Years of Change. London: Collings.

Cacciapuoti, Vincenzo. 1928. Relazioni commerciali tra l'Italia e la Russia, 1878-1927. Napoli: N. Jovenej.

Clarke, Roger A., and Dubravko J. I. Matko. 1983. Soviet Economic Facts, 1917-1981. 2d ed. New York: St. Martin's.

Conybeare, John A. C. 1984. "Public Goods, Prisoners' Dilemmas, and the International Political Economy." International Studies Quarterly 28:5-22.

Corden, Max. 1986. "The Normative Theory of International Trade." In International Trade: Surveys of Theory and Policy, ed. Ronald W. Jones. Amsterdam: North-Holland.

Correlates of War Project. 1991. National Material Capabilities Data. Ann Arbor: University of Michigan.

Deardorff, Alan V. 1984. "Testing Trade Theories and Predicting Trade Flows." In Handbook of International Economics, ed. Ronald W. Jones and P. B. Kenen. Amsterdam: NorthHolland.

Deardorff, Alan V., and Robert M. Stern. 1987. "Current
Issues in Trade Policy: An Overview." In U.S. Trade Policies in a Changing World Economy, ed. Robert Stern. Cambridge: Massachusetts Institute of Technology Press.

Doyle, Michael W. 1986. "Liberalism and World Politics." American Political Science Review 80:1151-69.

Duncan, George T., and Randolph M. Siverson. 1982. "Flexibility of Alliance Partner Choice in a Multipolar System: Models and Tests." International Studies Quarterly 26:511-38.

Fitzpatrick, Gary L., and Marilyn J. Modlin. 1986. Direct-Line Distances. Internat'l ed. Metuchen, NJ: Scarecrow.

Fox, John. 1991. Regression Diagnostics. Beverly Hills: Sage.

France. Bureau de la Statistique Generale. 1923. Annuare statistique de la France. Paris: Ministere du Commerce de l'Industy des Postes et des Telegraphs.

Frankel, Jeffrey A. 1992. "Is Japan Creating a Yen Bloc in East Asia and the Pacific?" Presented at the National Bureau of Economic Research conference, Japan and the United States in Pacific Asia, Del Mar, CA.

Frieden, Jeff. 1988. "Sectoral Conflict and U.S. Foreign Economic Policy." International Organization 42:59-90.

Fudenberg, Drew, and E. Maskin. 1986. "The Folk Theorem in Repeated Games with Discounting and Incomplete Information." Econometrica 52:87-100.

Fudenberg, Drew, and Jean Tirole. 1991. Game Theory. Cambridge: Massachusetts Institute of Technology Press.

Gochman, Charles S., and Zeev Maoz. 1984. "Militarized Interstate Disputes, 1816-1976: Procedures, Patterns, and Insights." Journal of Conflict Resolution 28:585-616.

Gowa, Joanne. 1989. "Bipolarity, Multipolarity, and Free Trade." American Political Science Review 83:1245-56.

Gowa, Joanne. N.d. Allies, Adversaries, and International Trade. Princeton: Princeton University Press. Forthcoming.

Gregory, Paul R. 1982. Russian National Income, 1885-1913. New York: Cambridge University Press.

Grenville, J. A. S. 1974. The Major International Treaties 19141973. London: Methuen.

Hirschman, Albert O. 1980. National Power and the Structure of Foreign Trade. Berkeley: University of California Press.

Keohane, Robert O. 1984. After Hegemony: Cooperation and Discord in the World Political Economy. Princeton: Princeton University Press.

Kindleberger, Charles P. 1973. The World in Depression, 19291939. Berkeley: University of California Press.

$\rightarrow$ Kreps, David M., Paul Milgrom, John Roberts, and Robert Wilson. 1982. "Rational Cooperation in the Finitely Repeated Prisoners' Dilemma." Journal of Economic Theory 27:245-52.

League of Nations. 1926. Memorandum on the Balance of Payments and Foreign Trade Balances, 1911-1925. Geneva: League of Nations.

League of Nations. 1933. International Trade Statistics, 1931 and 1932. Geneva: League of Nations.

Leamer, Edward E., and Robert M. Stern. 1970. Quantitative International Economics. Boston: Allyn \& Bacon.

Levy, Jack S. 1983. War in the Modern Great Power System, 1495-1975. Lexington: University Press of Kentucky.

Liesner, Thelma. 1989. One Hundred Years of Economic Statistics. Rev. ed. New York: Economist.

Linnemann, Hans. 1966. An Econometric Study of International Trade Flows. Amsterdam: North-Holland.

McKeown, Timothy J. 1982. "The Rise and Decline of the Open Trading Regime of the Nineteenth Century." Ph.D. diss. Stanford University.

McKeown, Timothy J. 1984. "Firms and Tariff Regime Change: Explaining the Demand for Protection." World Politics 36:215-33.

Maddala, G. S. 1988. Introduction to Econometrics. New York: Macmillan.

Magee, Stephen P., William A. Brock, and Leslie Young. 1989. Black Hole Tariffs and Endogenous Policy Theory: Political Economy in General Equilibrium. New York: Cambridge University Press.

Mansfield, Edward D. 1993. "The Effects of International Politics on Regionalism in International Trade." In Regional Integration and the Global Trading System. Eds. Kym Ander- 
son and Richard Blackhurst. London: Harvester Wheatsheaf.

Mansfield, Edward D. N.d. Power, Trade, and War. Princeton: Princeton University Press. Forthcoming.

Mitchell, Brian R. 1980. European Historical Statistics, 17501975. London: Butler \& Tanner.

Mitchell, Brian R. 1982. International Historical Statistics: Africa and Asia. New York: New York University Press.

Mitchell, Brian R. 1983. International Historical Statistics: The Americas and Australia. Detroit: Gale Research.

Oye, Kenneth A. 1992. Economic Discrimination and Political Exchange: World Political Economy in the 1930s and 1980s. Princeton: Princeton University Press.

Pelzman, Joseph. 1977. "Trade Creation and Trade Diversion in the Council of Mutual Economic Assistance: 1954-1970." American Economic Review 67:713-22.

Polachek, Solomon W. 1980. "Conflict and Trade." Journal of Conflict Resolution 24:55-78.

Pollins, Brian M. 1989a. "Does Trade Still Follow the Flag?" American Political Science Review 83:465-80.

Pollins, Brian M. 1989b. "Conflict, Cooperation, and Commerce: The Effects of International Political Interactions on Bilateral Trade Flows." American Journal of Political Science 33:737-61.

Powell, Robert. 1991. "Relative and Absolute Gains in International Relations." American Political Science Review 85: 1303-20.

Rasmusen, Eric. 1989. Games and Information: An Introduction to Game Theory. New York: Basil Blackwell.

Root, William A. 1984. "Trade Controls That Work." Foreign Policy 56:61-80.

Ruggie, John Gerard. 1982. "International Regimes, Transactions, and Change: Embedded Liberalism in the Postwar Economic Order." International Organization 36:379-415.

Siverson, Randolph M., and Juliann Emmons. 1991. "Birds of a Feather: Democratic Political Systems and Alliance Choices in the Twentieth Century." Journal of Conflict Resolution 35:285-306.

Small, Melvin, and J. David Singer. 1969. "Formal Alliances,
1816-1965: An Extension of the Basic Data." Journal of Peace Research 3:257-82.

Small, Melvin, and J. David Singer. 1982. Resort to Arms: International and Civil Wars, 1816-1980. Beverly Hills: Sage.

Snidal, Duncan. 1985. "Coordination Versus Prisoners' Dilemma: Implications for International Cooperation and $\mathrm{Re}-$ gimes." American Political Science Review 79:923-42.

Snidal, Duncan. 1991. "Relative Gains and the Pattern of International Cooperation." American Political Science Review 85:701-26.

Snyder, Glenn H. 1984. "The Security Dilemma in Alliance Politics." World Politics 36:461-95.

Snyder, Glenn H., and Paul Diesing. 1977. Conflict among Nations: Bargaining, Decision Making, and System Structure in International Crises. Princeton: Princeton University Press.

Srinivasan, T. N. 1987. “The National Defense Argument for Government Intervention in Foreign Trade." In U.S. Trade Policies in a Changing World Economy, ed. Robert M. Stern. Cambridge: Massachusetts Institute of Technology Press.

Tinbergen, Jan. 1962. Shaping the World Economy: Suggestions for an International Economic Policy. New York: Twentieth Century Fund.

Tirole, Jean. 1988. Industrial Organization. Cambridge: Massachusetts Institute of Technology Press.

U.S. Bureau of the Census. 1915. Statistical Abstracts of the United States. Washington: GPO.

U.S. Department of Commerce. 1934. Foreign Commerce Yearbook, 1933. Washington: GPO.

Waltz, Kenneth. 1979. Theory of International Politics. Reading: Addison-Wesley.

White, Halbert. 1980. "A Heteroskedasticity-Consistent Covariance Matrix Estimator and a Direct Test for Heteroskedasticity." Econometrica 48:817-38.

Yarbrough, Beth V., and Robert M. Yarbrough. 1992. Cooperation and Governance in International Trade: The Strategic Organizational Approach. Princeton: Princeton University Press.

Yeager, Leland B., and David G. Tureck. 1983/84. "Realism and Free-Trade Policy." Cato Journal 3:645-66.

Joanne Gowa is Professor of Politics, Princeton University, Princeton, NJ 08544.

Edward D. Mansfield is Assistant Professor of Political Science, Columbia University, New York, NY 10027. 